\title{
Terrigenous flux and biogenic silica deposition at the Antarctic continental rise during the late Miocene to early Pliocene: implications for ice sheet stability and sea ice coverage
}

\author{
Jens Grützner ${ }^{\mathrm{a}, *}$, Claus-Dieter Hillenbrand ${ }^{\mathrm{b}, 1}$, Michele Rebesco $^{\mathrm{c}}$ \\ ${ }^{\mathrm{a}}$ Geosciences Department, Bremen University, P.O. Box 330440, 28334 Bremen, Germany \\ ${ }^{\mathrm{b}}$ Alfred Wegener Institute for Polar and Marine Research, P.O. Box 120161, D-27515 Bremerhaven, Germany \\ ${ }^{c}$ Istituto Nazionale di Oceanografia e di Geofisica Sperimentale, Borgo Grotta Gigante 42/C, 34010 Sgonico, Italy
}

Received 24 November 2003; accepted 28 September 2004

\begin{abstract}
Drift sediments recovered from the East Antarctic continental rise at Ocean Drilling Program (ODP) Site 1165 are used to infer variations in East Antarctic Ice Sheet (EAIS) stability and sea ice coverage during the late Miocene and early Pliocene. A significant increase in the deposition of biogenic opal from $\sim 5.8$ to 5.2 Ma points to an early Pliocene reduction in sea ice and a subsequent increase in biological productivity. Time intervals at $\sim 7.2$ to $6.6 \mathrm{Ma}$ and $\sim 5.2$ to $4.8 \mathrm{Ma}$ are characterized by pronounced maxima in the long-term trend of terrigenous matter accumulation $\left(\mathrm{MAR}_{\text {ter }}\right)$ indicating high continental erosion rates potentially caused by ice sheet growth. A Southern Ocean wide impact of these events is suggested by similar evidence found at ODP Site 1095 (Antarctic Peninsula). Superimposed on the $\mathrm{MAR}_{\text {ter }}$ maxima we observe enhanced orbital variability in iron accumulation at Site 1165 pointing to a dynamic behavior of the EAIS with waxing and waning ice masses. From the concurrence of these high amplitude ice sheet fluctuations with maximum variance in Earth's obliquity, we propose that the insolation gradient between high and low latitudes affected the delivery of moisture to Antarctica and thus controlled ice volume variations.
\end{abstract}

(C) 2004 Elsevier B.V. All rights reserved.

Keywords: Palaeoclimatology; Ocean Drilling Program; Antarctic ice sheet; Milankovitch theory; Neogene

* Corresponding author. Tel.: +49 421 2182482; fax: +49 421 2183116.

E-mail address: jgruetzn@allgeo.uni-bremen.de (J. Grützner).

${ }^{1}$ Present address: British Antarctic Survey, High Cross Madingley Road, Cambridge CB3 0ET, United Kingdom.

\section{Introduction}

Compilations of benthic oxygen isotope data reveal that global climate during the Neogene exhibits a general cooling trend that is linked to cryospheric evolution (Zachos et al., 2001). The cooling did not proceed uniformly, with the $\delta^{18} \mathrm{O}$ record exhibiting a number of steps and peaks that reflect episodes of 
global warming and cooling. However, the relationship between these more rapid transitions in the $\delta^{18} \mathrm{O}$ record, the evolution of the Antarctic climate, and ice volume changes is not fully understood. Of particular interest in this context are major glaciations of the late Miocene (e.g. Kennett and Barker, 1990; Billups, 2002) and the subsequent warming trend during the early Pliocene (e.g. Poore and Sloan, 1996; Whitehead and Bohaty, 2003).

For the late Miocene, major cooling episodes with increasing global ice volume are reported (see review by Hodell and Kennett, 1986). Prominent glacial to interglacial oscillations occur (Hodell et al., 2001) and glacioeustatic sea level falls of up to $40-60 \mathrm{~m}$ are associated with the glacial episodes (Shackleton and Kennett, 1975; Hodell and Kennett, 1986; Hodell et al., 1994). However, a late Miocene increase in global ice volume is not ubiquitously recorded in late Miocene benthic foraminiferal $\delta^{18} \mathrm{O}$ records (Hodell et al., 2001; Billups, 2002). In Antarctica erosional unconformities on the Prydz Bay continental shelf (Hambrey et al., 1991) and maxima in the accumulation of ice rafted material at the Kerguelen Plateau (Ehrmann et al., 1991; Joseph et al., 2002) suggest that the Lambert Glacier/Amery Ice Shelf complex temporarily had a larger extension than at present day.

In contrast to the late Miocene, the early Pliocene is thought to be a time of global climate warming and much evidence exists that enhanced oceanic heat transport played a significant role in sustaining high latitude warmth during this period (e.g. Billups et al., 1998, 1999; Kwiek and Ravelo, 1999; Ravelo and Andreasen, 2000). The effect of the late Miocene/early Pliocene warming on Antartic ice volume is still controversial, despite 17 years of research on the topic (see summaries by Barker, 1995; Wilson, 1995; Kennett and Hodell, 1995). Interpretations of the eustatic sea-level curve, oxygen isotope records of benthic foraminifera, cosmogenic exposure ages of Antarctic hard rocks, and ice sheet modelling (e.g. Huybrechts, 1993; Sugden et al., 1993; Kennett and Hodell, 1995; Lear et al., 2000; Zachos et al., 2001) support the idea that the East Antarctic Ice Sheet (EAIS) reached its present size at approximately $14 \mathrm{Ma}$ and has changed little since then, due to thermal isolation by the cold, circum-Antarctic current (stability hypothesis). A competing hypothesis (deglaciation scenario), supported by the presence of Pliocene marine diatoms and fossils of terrestrial plants and vertebrates in the Pliocene Sirius Group (e.g. Webb et al., 1984; Hambrey and McKelvey, 2000), suggests that Antarctic ice sheets may have decreased to as much as one-third of the present volume. On the other hand, evidence for early Pliocene ice advances onto the continental shelf has been found in seismic reflection profiles (Bart, 2001).

Associated with the climate variations during the Neogene are changes in glacial regime which have altered the style of erosion and deposition. During late Miocene and early Pliocene time, the EAIS was likely more dynamic with greater glacial sediment erosion than would occur with a stable, cold-based ice sheet such as today (e.g. Harwood and Webb, 1998). Neogene facies associations from the Pagodroma Group in the Lambert Glacier region resemble deposits known from polythermal glaciers of the East Greenland margin, rather then those from modern Antarctic ice margins (Hambrey and McKelvey, 2000). Reduced sea-ice coverage on the East Antarctic continental shelf is inferred from low abundance of extant sea-ice diatoms in the Pliocene section of the Sørsdal Formation (e.g. Pickard et al., 1988; Whitehead et al., 2001).

Superimposed on changes in the long-term trend of global climate are higher frequency changes $\left(10^{4}\right.$ to $10^{5}$ years), generated by periodic and quasiperiodic oscillations in Earth's orbital parameters of eccentricity, obliquity, and precession, which affect the distribution and amount of incident solar energy (Hays et al., 1976). The response of the Antarctic ice sheet to these insolation changes is not well understood. Evidence for significant variations of the EAIS volume at orbital frequencies is documented for the Oligocene-Miocene boundary (Naish et al., 2001), for the late Miocene (Grützner et al., 2003) and for the Pliocene and Pleistocene. Drift sediments recovered during ODP Leg 178 at the Antarctic Peninsula continental rise also exhibit a pronounced cyclicity but in contrast to ODP Leg 188 Site 1165 spectral analysis of sedimentary parameters at ODP Leg 178 Sites 1095 and 1096 did not show the dominance of frequencies usually associated with orbital insolation variation (Lauer-Leredde et al., 2002; Pudsey, 2001). Therefore, it is uncertain if the glacial-interglacial cyclicity in sediment deposition off the Antarctic Peninsula before the late Pliocene- 
Pleistocene growth of large Northern Hemisphere ice sheets was orbitally driven or essentially caused by autocyclic Antarctic Peninsula Ice Sheet (APIS) oscillations (Barker and Camerlenghi, 2002).

Here we report on the sediment record recovered at ODP Site 1165, which was drilled into the Wild Drift, Prydz Bay continental rise (Shipboard Scientific Party, 2001). We focus on the time interval 3.4 to $7.6 \mathrm{Ma}$, which includes the prominent glacial episodes during the late Miocene and the Pliocene. Depositional rates of biogenic opal are used to examine changes in diatom productivity caused by fluctuations in annual sea ice coverage in the Cooperation Sea. Additionally, the dynamics of the EAIS are inferred from the accumulation rates of terrigenous components deposited at Site 1165, which are assumed to reflect the supply of glaciogenic detritus to the ocean. Furthermore, we present measurements of sediment color and iron content as high resolution proxies for productivity and continental erosion, providing insights into climate variability on orbital time scales.

The findings at ODP Site 1165 (Prydz Bay) are compared to results from ODP Site 1095 (Antarctic Peninsula) and ODP Leg 177 Site 1088 (Agulhas Ridge, Southern Ocean) in order to explore similarities and differences in the evolution of East and West Antarctic margins in relation to ice sheet dynamics and oceanographic changes in the Southern Ocean.

\section{Setting}

The most continuous ice proximal sedimentary sequences offshore Antarctica have been recovered from continental rise drifts (ODP Legs 178 and 188), and contain excellent high-resolution records of climate variability. Prerequisites for drift formation are abundant sediment supply and moderate bottom current flow. Seismic reflection profiles across most drifts around Antarctica show steady deposition of finegrained sediments under slow bottom current conditions (e.g. Kuvaas and Leitchenkov, 1992; Rebesco et al., 2002; Michels et al., 2002; Escutia et al., 2002).

Site 1165 is situated in a water depth of $3357 \mathrm{~m}$ on the continental rise offshore from Prydz Bay seaward of the Amery Ice Shelf that merges with the Lambert Glacier (Fig. 1). This system today drains about $22 \%$ of East Antarctica, acting as a focused sediment outlet
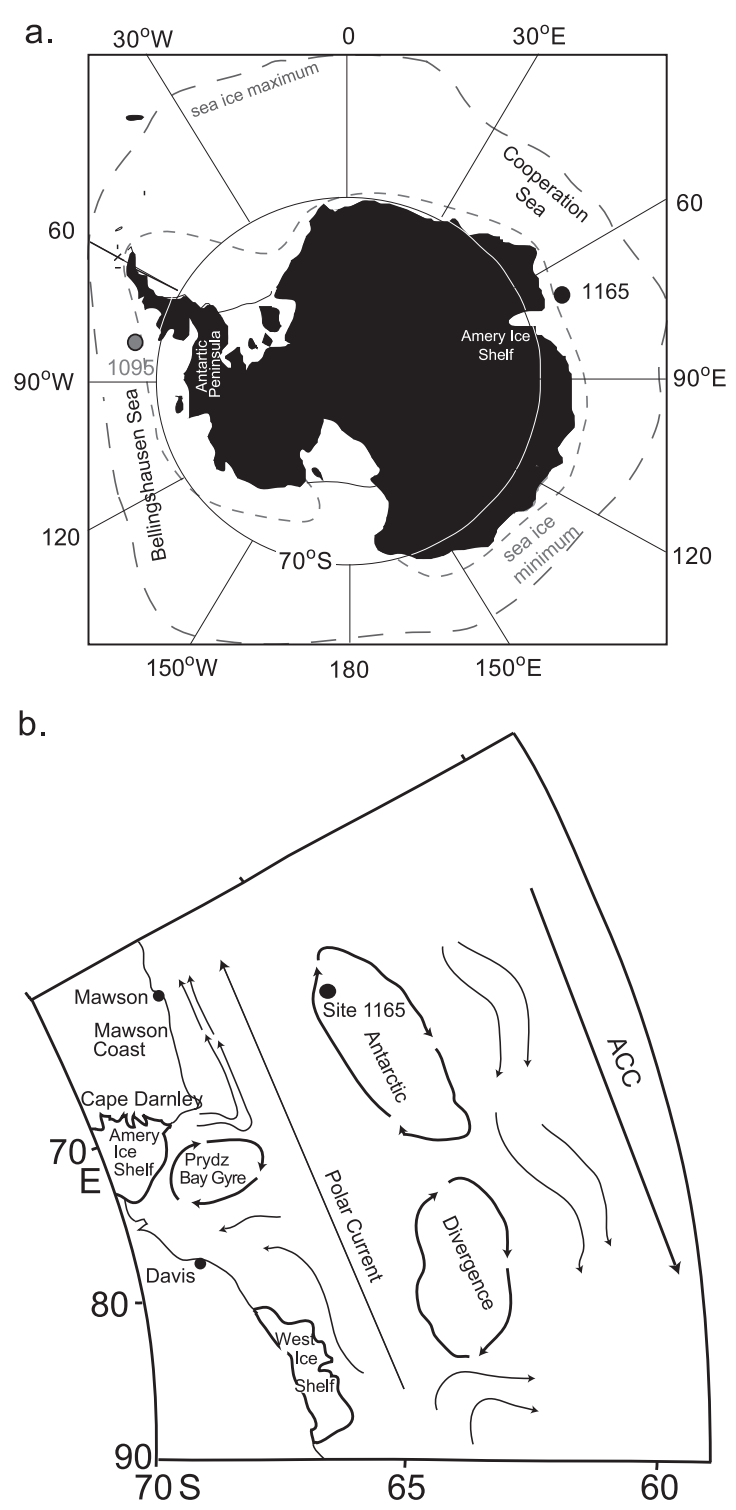

Fig. 1. Locations of ODP Sites 1165 (black) and 1095 (gray) drilled into drift sediments at the continental rise of Antarctica. Also shown is the sea ice distribution in the Southern Ocean (modified after Gersonde et al., 1999). (b) Site 1165 is located on the central Wild Drift which is close to the margin of the Antarctic Divergence, a series of cyclonic gyres at the boundary between the Antarctic Circumpolar Current (ACC) and the Polar Current. These major currents move in opposite directions and extend into Antarctic deep water.

to the sea (Anderson et al., 1991; Hambrey et al., 1991). The site was drilled into hemipelagic sediments of the central Wild Drift, an elongate sediment body 
formed in the Cooperation Sea (Kuvaas and Leitchenkov, 1992). Deep-water movements over the Wild Drift are attributed to three large-scale ocean systems (Smith et al., 1984): The Polar Current (PC), moving west near the shelf edge; the Antarctic Divergence (AD), producing cyclonic-gyres over the slope and upper rise; and the Antarctic Circumpolar Current (ACC), flowing eastward over the lower rise and beyond (Fig. 1b). Antarctic Bottom Water (AABW) is not actively formed in large quantities in Prydz Bay, where waters are only moderately saline (Wong et al., 1998). The large-scale geometry of seismic reflectors suggests that most of the drift growth took place within a prevailing west-flowing current (Kuvaas and Leitchenkov, 1992). It is hence very likely that Wild Drift sediments were deposited at the edge of the PC laden with the terrigenous detritus discharged from the Prydz Bay Trough.

The $999 \mathrm{~m}$ deep drillhole at Site 1165 recovered a fine grained (muddy) sedimentary sequence, characterized by alternating gray to dark gray terrigenous facies and a green to greenish gray hemipelagic facies (Shipboard Scientific Party, 2001). The greenish facies are structureless diatom-bearing clays containing dispersed clasts and lonestones. The dark gray facies mainly consists of clay with some silt laminae. Above $63.8 \mathrm{~m}$ below seafloor (mbsf) the number of silt laminae is much less compared to the lower part of the section, indicating that contour current driven terrigenous sedimentation at the Wild Drift became less significant from $\sim 6.1 \mathrm{Ma}$ onward. As a consequence of low sedimentation rates during the Pleistocene and late Pliocene (Shipboard Scientific Party, 2001), undisturbed upper Miocene and lower Pliocene sections at Site 1165 were drilled in relatively shallow burial depth using the hydraulic piston corer (HPC). Here we investigate cores $1165 \mathrm{~B}-4 \mathrm{H}$ to $11 \mathrm{H}(30-100 \mathrm{mbsf})$. A gap in HPC coring was filled by investigating rotary core $1165 \mathrm{C}-1 \mathrm{R}$.

A similar upper Miocene to lower Pliocene section of drift sediments was recovered at Site 1095 (Antartic Peninsula), which lies in $3840 \mathrm{~m}$ water depth on the northwestern distal flank of a hemipelagic sediment drift (Drift 7) in the Bellingshausen Sea. Sedimentation there was characterized by alternations between a grayish-green massive facies and gray laminated, terrigenous silts and muds. The thin laminated intervals indicate a depositional environment domi- nated by turbidites (Shipboard Scientific Party, 1999; Pudsey, 2001). As a consequence of the higher sedimentation rates at Drift 7 compared to the Wild Drift the time interval 7.6 to $3.4 \mathrm{Ma}$ is much deeper at Site 1095 ( $\sim 90-320 \mathrm{mbsf})$.

\section{Methods}

\subsection{Measurements}

Opal-A content was measured on 96 samples (1-2 per section) from Cores $188-1165 \mathrm{~B}-4 \mathrm{H}$ through $11 \mathrm{H}$ and Core 188-1165C-1R. Homogenized dry bulk samples were analyzed using an automated leaching technique after Müller and Schneider (1993). Results are given as weight percent biogenic silica by assuming a uniform bound water content of $10 \mathrm{wt} . \%$ within the opaline substance. According to Müller and Schneider (1993), the relative accuracy of the method is better than $2 \%$ for samples rich in biogenic silica and $4 \%-10 \%$ for samples with $<10$ wt. $\%$ biogenic silica, respectively. Because carbonate percentages are very low $(<1 \%$, Shipboard Scientific Party, 2001) the sediments at Site 1165 can be regarded as a two component system consisting of biosiliceous and terrigenous material. Thus the weight percentage terrigenous material $\left(\%_{\text {ter }}\right)$ was calculated using $\%_{\text {ter }}=100 \%_{\text {opal }}$. Opal-A percentages for Site 1095 were provided by Hillenbrand and Fütterer (2001).

Color reflectance measurements were made at the surface of split cores. The CM-2002 photospectrometer was used to measure the hue and chroma attributes of the sediments as well as the reflected visible light in 31, 10-nm-wide bands ranging from 400 to $700 \mathrm{~nm}$ (e.g. Balsam et al., 1997). These measurements were taken at the time of core collection, at a resolution of $5 \mathrm{~cm}$. An inspection of the photospectrometer data (Rebesco, 2003) revealed that the color cycles are best described by the ratio of the average reflectivity in the $500-590 \mathrm{~nm}$ band (green) and the average reflectivity of all spectral bands (gray).

The chemical element composition of the sediment was analyzed using a XRF core scanner, a nondestructive analysis system for scanning the surface of archive halves of cores. The general method and some calibration procedures are described by Jansen et al. (1998). Our system configuration (Röhl and Abrams, 
2000) allows the analysis of elements from potassium $(\mathrm{K}$, atomic number 19$)$ through strontium $(\mathrm{Sr}$, atomic number $38 ; 20 \mathrm{kV}$ X-ray voltage). The XRF data were collected at $1 \mathrm{~cm}$ intervals at Site 1165 and at $2 \mathrm{~cm}$ intervals at Site 1095. Measurements were made over a $1 \mathrm{~cm}^{2}$ area, with $15 \mathrm{~s}$ count time and an X-ray current of $0.15 \mathrm{~mA}$ to obtain statistically significant data of the elements we were interested in (e.g. K, Ca, $\mathrm{Fe}, \mathrm{Ti}, \mathrm{Sr}$ ). In this paper, we use $\mathrm{Fe}$ data to infer content of terrigenous detritus at a high resolution, because this element is primarily deposited with the siliciclastic sediment component $\left(\%_{\text {ter }}\right.$ and Fe correlate with $r=0.54$ ) and the iron intensity shows very pronounced amplitude changes. Measurements of titanium (Ti), which is redox-insensitive, show an identical downcore pattern. Hence, Fe variations at Sites 1165 and 1095 within the studied interval are not diagenetically controlled. The iron intensity counts were calibrated with ICP-ES analyses (Murray et al., 2000) on discrete samples to derive Fe concentrations (Grützner et al., 2003).

\subsection{Stratigraphy}

The time series presented for Sites 1165 were calculated by linear interpolation between age control points resulting from the integration of the microfossil biostratigraphy and paleomagnetic data (Florindo et al., 2003).

The age model used for Site 1095 (Acton et al., 2002) is based on magnetostratigraphy. Ages reported by both Florindo et al. (2003) and Acton et al. (2002) are consistent with the geomagnetic polarity time scale (GPTS) of Cande and Kent (1995). In order to compare the time series for Site 1165 with orbitally tuned paleoceanographic records from other ocean basins we use here the astronomical calibrated time scale of Hilgen et al. (1995), which deviates only slightly from the GPTS (Table 1) for the interval we are interested in. The oldest magnetic polarity reversal identified within depth interval investigated at Site 1165 is C3Ar to C3Bn (at 89.20 mbsf, Florindo et al., 2003) that has an age of $6.935 \mathrm{Ma}$ (Cande and Kent, 1995). In order to extrapolate the time span to be investigated we therefore make use of a tie point (99.05 mbsf, 7.467 Ma) derived from astronomical tuning of a short sedimentary section (Grützner et al., 2003). Furthermore, we use a datum $(7.8 \mathrm{Ma})$ at
Table 1

Age model for Site 1165 after Florindo et al. (2003), Grützner et al. (2003), and Hilgen et al. (1995)

\begin{tabular}{lll}
\hline Depth (mbsf) & Age $(\mathrm{ky})$ & Method \\
\hline 19.23 & 3032 & Magnetostratigraphy \\
20.91 & 3116 & Magnetostratigraphy \\
25.96 & 3207 & Magnetostratigraphy \\
30.76 & 3330 & Magnetostratigraphy \\
36.46 & 3596 & Magnetostratigraphy \\
42.06 & 4188 & Magnetostratigraphy \\
43.19 & 4300 & Magnetostratigraphy \\
45.75 & 4632 & Magnetostratigraphy \\
46.96 & 4799 & Magnetostratigraphy \\
48.8 & 4896 & Magnetostratigraphy \\
49.12 & 4998 & Magnetostratigraphy \\
54.56 & 5236 & Magnetostratigraphy \\
73.52 & 6677 & Magnetostratigraphy \\
89.2 & 7101 & Magnetostratigraphy \\
99.05 & 7467 & Orbital tuning \\
103.22 & 7800 & Radiolarian datum \\
\hline
\end{tabular}

103.22 mbsf that is based on radiolarian biostratigraphy (Florindo et al., 2003).

\subsection{Spectral analyses}

In order to investigate the periodicities in the high resolution time series of iron accumulation we use Singular Spectrum Analysis (SSA, Vautard et al., 1992) and spectral analyses algorithms (Program REDFIT, Schulz and Mudelsee, 2002) based on the Lomb-Scargle Fourier transform (Lomb, 1976; Scargle, 1982).

Singular Spectrum Analysis (SSA) a data-adaptive method based on the principal component analysis (PCA) of an augmented time series is used to decompose the obtained time series into a trend, oscillatory components and noise. Each PCA contains significant parts of the spectrum and convolution of two or more PCAs with their corresponding empirical orthogonal functions (EOFs) can be used to reconstruct a specific bandwidth (reconstructed components, RCs) of the original signal (Vautard et al., 1992). The resulting outputs are data adaptive filters, but unlike band pass filtering SSA provides an independent spectral estimation.

The program REDFIT is used to test if spectral peaks in the oscillatory signal components are significant against a red noise background. Furthermore, the software ENVELOPE (Schulz et al., 
1999), like REDFIT designed for unevenly spaced time series, is used to estimate temporal changes in amplitude (=signal envelope) of cyclic signal components applying a modified version of the harmonic-filtering algorithm of Ferraz-Mello (1981), which fits a sinusoidal wave to a time series by means of least-squares.

\section{4. "Proxies"}

Sedimentological, geochemical and physical sediment properties measured at Site 1165 as well as newly derived geochemical data from Site 1095 can be downloaded from the PANGAEA database (www.pangaea.de). Our interpretation is based on time series of mass accumulation rates and depositional rates calculated from these parameters.

\subsection{Mass accumulation rates of terrigenous sediment components}

We investigate the variability of ice coverage on East Antarctica during the late Miocene and early
Pliocene time using mass accumulation rates of terrigenous sediment $\left(\mathrm{MAR}_{\text {ter }}\right)$ and iron $\left(\mathrm{MAR}_{\mathrm{Fe}}\right)$ at the Wild Drift. We assume that sediments deposited on the Antarctic rise largely derive from glaciogenic debris transported by ice advance across the glacial margin, and that redeposition by gravitational downslope processes and current transport did not mask the primary signal of the supply of terrigenous detritus (e.g. Hallet et al., 1996; Joseph et al., 2002). Thus $\mathrm{MAR}_{\text {ter }}$ and $M A R_{\mathrm{Fe}}$ at the continental rise should be relatively high during ice advance, yet should decrease once the ice sheet stabilizes.

Accumulation rates (in $\mathrm{g} / \mathrm{cm}^{2} / \mathrm{ky}$ ) of bulk sediment (MAR), iron $\left(\mathrm{MAR}_{\mathrm{Fe}}\right)$, biogenic silica $\left(\mathrm{MAR}_{\mathrm{opal}}\right)$, and terrigenous material $\left(\mathrm{MAR}_{\text {ter }}\right)$ were calculated using the equation:

$\mathrm{MAR}_{\text {component }}=\operatorname{LSR} \times \rho_{\mathrm{DB}} \times \operatorname{comp}[\%] / 100$,

where LSR is the linear sedimentation rate (in $\mathrm{cm} / \mathrm{ky}$ ), $\rho_{\text {DB }}$ is the dry bulk density (in $\mathrm{g} / \mathrm{cm}^{3}$ ) derived from gamma ray attenuation (GRA) bulk density measurements ( $2 \mathrm{~cm}$ sampling interval, Grützner, 2003), and comp is the weight percentage of the individual sediment components.

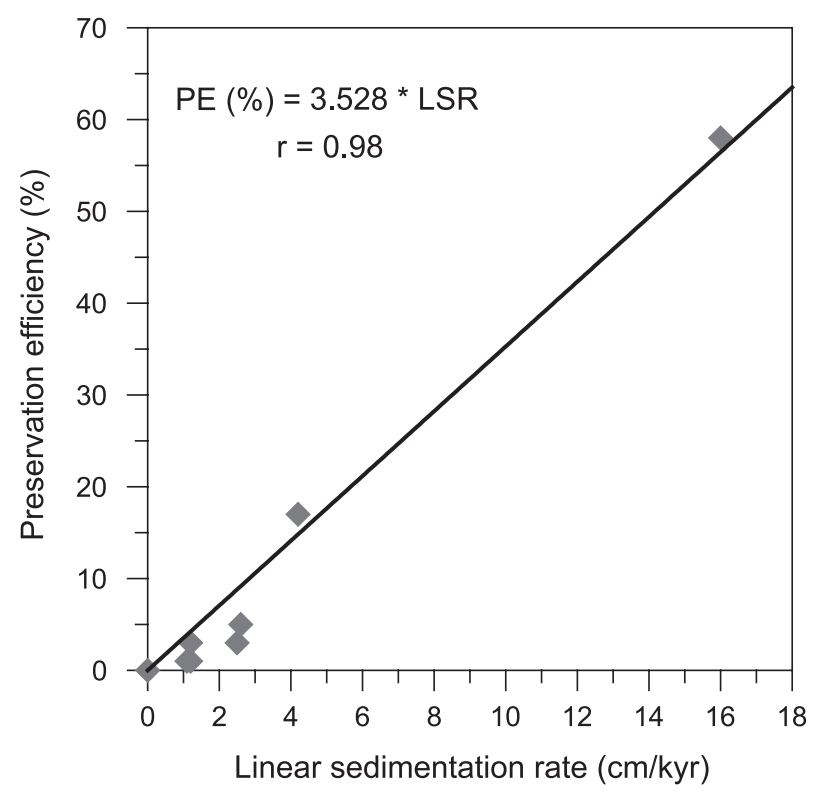

Fig. 2. Correlation between the opal seabed preservation efficiency (the ratio of opal accumulation rate in the surface sediment, $\mathrm{MAR}_{\mathrm{opal}}$, to the original opal depositional rate on the seabed) and the linear sedimentation rate (LSR) for Antarctic continental margin deposits in the Ross Sea (derived from DeMaster et al., 1996). 


\subsection{Opal depositional rates}

The sea ice cover that surrounds Antarctica is related to regional climate on the Antarctic continent and to the heat budget of Southern Ocean water masses (Armand, 2000). Consequently, the reconstruction of past changes in sea-ice coverage is crucial to understand variations of Antarctic climate. In the seasonally sea-ice covered areas, biological productivity is closely linked to sea ice conditions because the major part of the annual flux to the seafloor of diatom tests occurs during the months with open-water conditions, whereas ice-covered periods are characterized by very low diatom sedimentation $(<5 \%$ of annual flux). Thus, reconstructions of biogenic productivity derived from measurements of biogenic opal in marine sediments have been used to estimate past sea ice conditions in the Southern Ocean (e.g. Burckle and Mortlock, 1998; Hillenbrand and Fütterer, 2001).

The accumulation of biogenic material at the seafloor is controlled by production of particulate biogenic silica in surface waters, dissolution in the water column, and dissolution within the sediment column. Diagenetic dissolution of opal within the sediment column predominantly takes place in the surface sediments (e.g. Schlüter et al., 1998). In general, a higher flux of other sedimentary constituents leads to more rapid burial and, subsequently, to better opal preservation (e.g. Archer et al., 1993; Ragueneau et al., 2000). Thus the accumulation rate of terrigenous particles plays a major role for opal accumulation in the seabed and variations in $\mathrm{MAR}_{\text {ter }}$ can mask the biological productivity signal in $\mathrm{MAR}_{\text {opal. }}$. In accordance with Hillenbrand and Fütterer (2001), we use the preservation efficiency (PE), i.e.

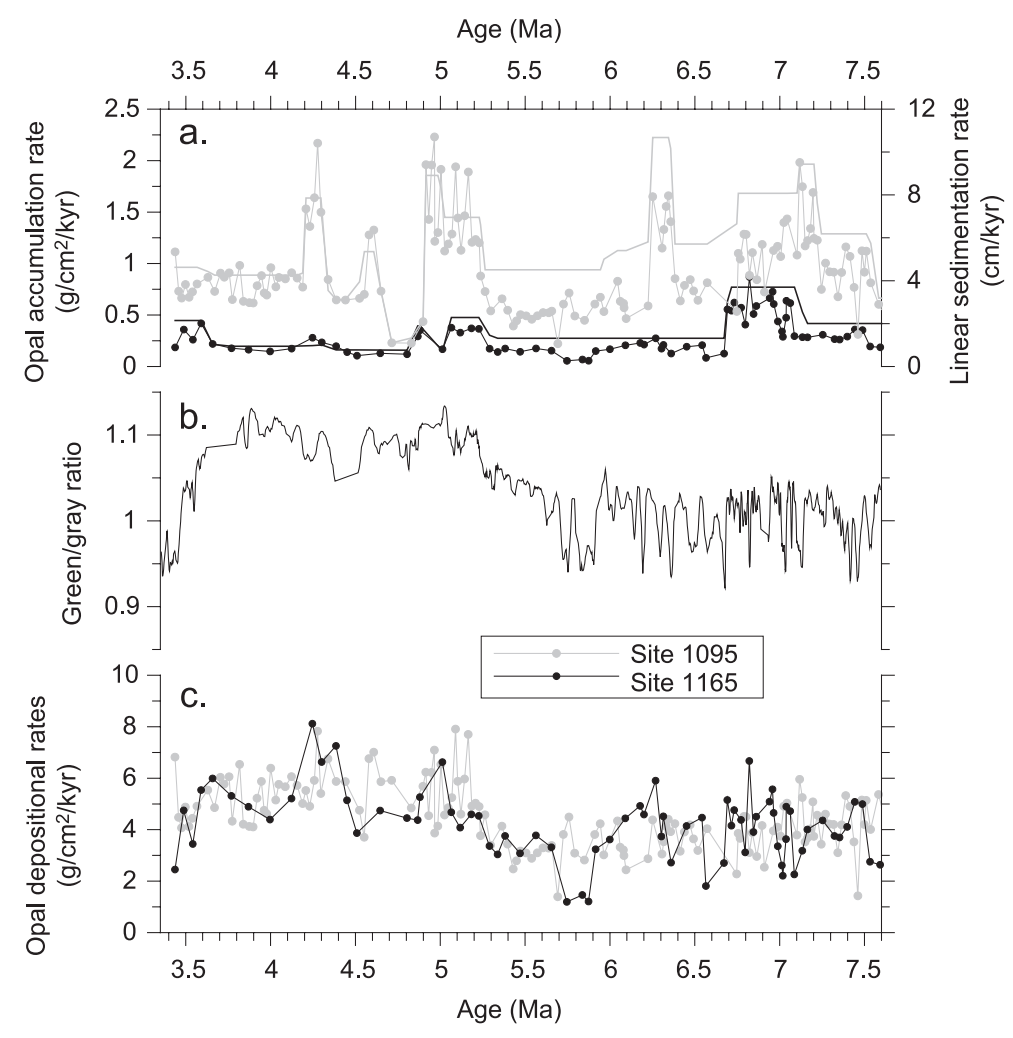

Fig. 3. (a) Opal accumulation rates $\left(\mathrm{MAR}_{\mathrm{opal}}\right)$ at Sites 1165 and 1095 (dots) compared to linear sedimentation rates (LSR). (b) Green/gray color ratio at Site 1165. (c) Opal depositional rates $\left(\mathrm{DEP}_{\text {opal }}\right)$ at Sites 1165 and 1095. 
the ratio of opal accumulation in the surface sediment to the original opal deposition on the seabed, to overcome this problem:

$$
\mathrm{PE}=\mathrm{MAR}_{\mathrm{opal}} / \mathrm{DEP}_{\mathrm{opal}}
$$

PE shows a positive correlation to LSR for various sites in the Ocean (Ragueneau et al., 2000 and references therein), and here we use the data set of DeMaster et al. (1996) for continental margin sedi- ments in the Ross Sea to derive a linear regression equation (Fig. 2):

$\mathrm{PE}[$ dimensionless $]=0.035282[\mathrm{ky} / \mathrm{cm}] \times \operatorname{LSR}[\mathrm{cm} / \mathrm{ky}]$.

Subsequently, opal depositional rates $\left(\mathrm{DEP}_{\text {opal }}\right)$ were calculated from:

$$
\begin{gathered}
\operatorname{DEP}_{\text {opal }}\left[\mathrm{g} / \mathrm{cm}^{2} / \mathrm{ky}\right]=\operatorname{MAR}_{\text {opal }}\left[\mathrm{g} / \mathrm{cm}^{2} / \mathrm{ky}\right] \\
/(0.035282[\mathrm{ky} / \mathrm{cm}] \times \operatorname{LSR}[\mathrm{cm} / \mathrm{ky}])
\end{gathered}
$$

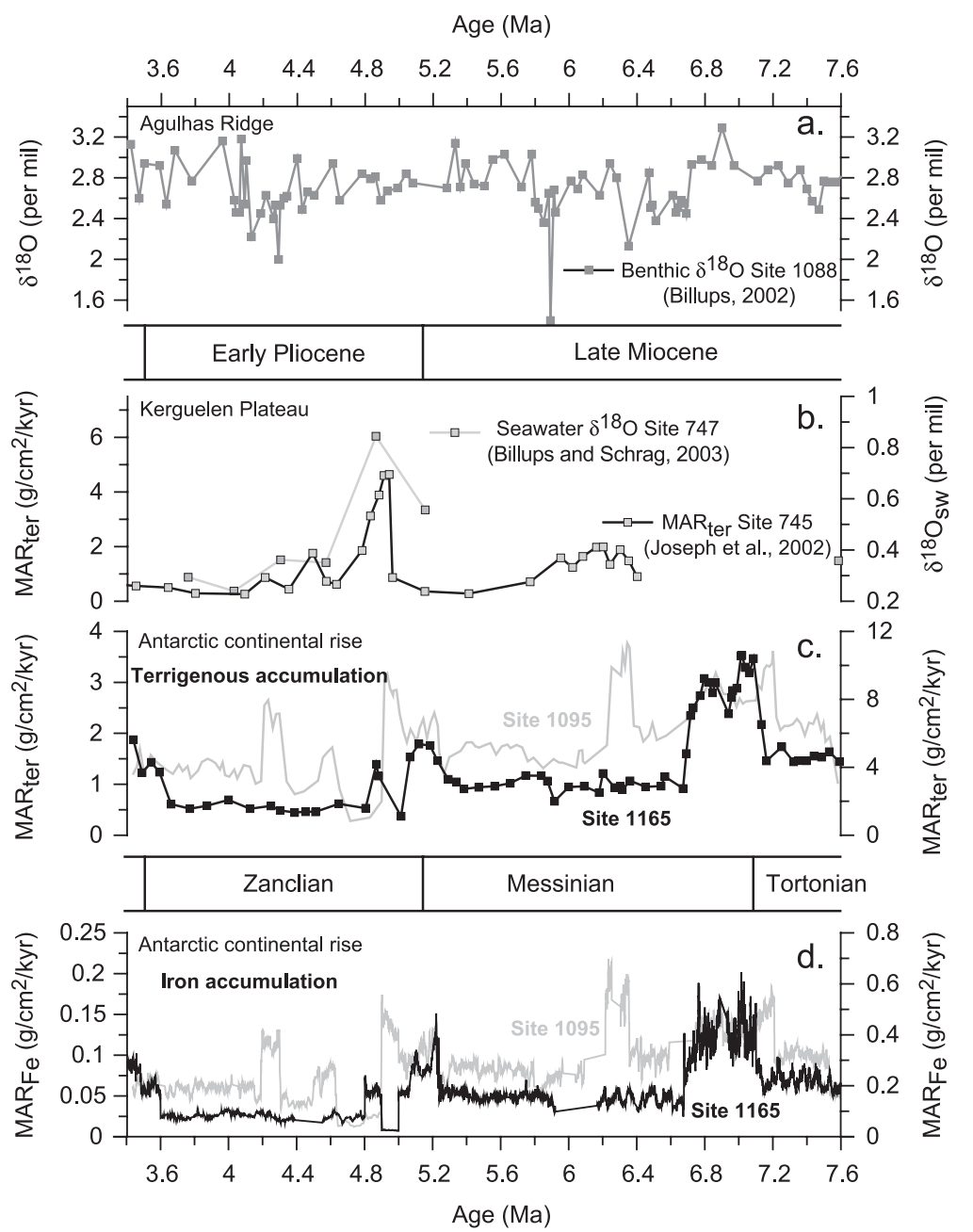

Fig. 4. (a) Late Miocene/early Pliocene benthic foraminiferal oxygen isotope record (Billups, 2002) from Site 1088 (Southern Ocean). (b) Oxygen isotope record of seawater $\left(\delta^{18} \mathrm{O}_{\mathrm{sw}}\right)$ and mass accumulation rate of terrigenous material $\left(\mathrm{MAR}_{\mathrm{ter}}\right)$ at the Kerguelen Plateau. $\delta^{18} \mathrm{O}_{\mathrm{sw}}$ is derived from paired $\delta^{18} \mathrm{O}$ and $\mathrm{Mg} / \mathrm{Ca}$ measurements on benthic foraminifera and is interpreted to reflect global ice volume. (c-d) Mass accumulation rates of terrigenous material $\left(\mathrm{MAR}_{\mathrm{ter}}\right)$, and iron $\left(\mathrm{MAR}_{\mathrm{Fe}}\right)$ at Site 1165 (East Antarctica, left $y$-axes) in comparison to Site 1095 (Antarctic Peninsula, right $y$-axes). 
The derived equation is slightly different from the one used by Hillenbrand and Fütterer (2001) as we forced the regression through the origin of the graph (Fig. 2) to avoid artifacts arising from negative opal preservation for the relatively low LSR at Site 1165. Forcing the regression through the origin reduces the coefficient of determination $(r)$ only slightly from 0.99 to 0.98 . $\mathrm{DEP}_{\text {opal }}$ at Site 1095 were recalculated using the new equation. Recalculated $\mathrm{DEP}_{\text {opal }}$ is, on average, only $0.4 \mathrm{~g} / \mathrm{cm}^{2} / \mathrm{ky}$ lower compared to that published by Hillenbrand and Fütterer (2001) but preserves the long-term trend and also shorter term variations.

$\mathrm{MAR}_{\text {opal }}$ and LSR are up to four times lower at Site 1165 compared to Site 1095 (Fig. 3a). Since these sites lie within the same surface water mass (Antarctic surface water), under the influence of similar sea ice conditions (Fig. 1), we would not expect large differences in biogenic productivity. Thus, the continuously lower $\mathrm{MAR}_{\text {opal }}$ at Site 1165 with respect to Site 1095 is interpreted to reflect a higher dissolution of biosiliceous particles, due to lower terrigenous supply at the Wild Drift. We, therefore, use opal depositional rates $\left(\mathrm{DEP}_{\text {opal }}\right)$ at Site 1165 to investigate past sea ice variations in the Cooperation Sea.

\section{Results}

At Site 1165, as well as at Site $1095, \mathrm{DEP}_{\text {opal }}$ fluctuate around $4 \mathrm{~g} / \mathrm{cm}^{2} / \mathrm{ky}$ during the late Miocene (Fig. 3c). Centered at $\sim 5.7 \mathrm{Ma}$ a pronounced $\mathrm{DEP}_{\text {opal }}$ minimum $\left(<2 \mathrm{~g} / \mathrm{cm}^{2} / \mathrm{ky}\right)$ occurs at Site 1165 , whereas this minimum is less pronounced at Site 1095. After $\sim 5.7$ Ma deposition increased until $\sim 5.2 \mathrm{Ma}$ (Fig. 3c). During the early Pliocene $\mathrm{DEP}_{\text {opal }}$ exhibits variations around $6 \mathrm{~g} / \mathrm{cm}^{2} / \mathrm{ky}$ with a maximum $\left(8 \mathrm{~g} / \mathrm{cm}^{2} / \mathrm{ky}\right)$ at $\sim 4.3 \mathrm{Ma}$. Typical late Quaternary $\mathrm{DEP}_{\text {opal }}$ for Antarctic continental margin are in the range of 1 to $3 \mathrm{~g} / \mathrm{cm}^{2} /$ ky (Schlüter et al., 1998; Hillenbrand and Fütterer, 2001). Thus, we infer that sea ice coverage in the Cooperation Sea and Bellingshausen Sea was slightly lower during the Late Miocene and significantly reduced during the early Pliocene when compared with the present-day situation.

Terrigenous detritus supplied by glacial erosion comprises the main part ( $75 \%$ to $95 \%)$ of the bulk sediment at Site 1165. This terrigenous flux under- went significant changes during the late Miocene and early Pliocene (Fig. 4). There is a general trend to lower $\mathrm{MAR}_{\text {ter }}$ from $1.5 \mathrm{~g} / \mathrm{cm}^{2} / \mathrm{ky}$ at $7.6 \mathrm{Ma}$ to $0.5 \mathrm{~g} /$ $\mathrm{cm}^{2} / \mathrm{ky}$ at 3.6 Ma (Fig. 4c). Synchronous maxima in $\operatorname{MAR}_{\text {ter }}\left(2-4 \mathrm{~g} / \mathrm{cm}^{2} / \mathrm{ky}\right.$ at Site 1165$)$ at Sites 1165 and 1095 occurred from 7.2 to 6.6 Ma and from 5.2 to 4.8 Ma, respectively. At Site $1095, \mathrm{MAR}_{\text {ter }}$ was additionally elevated at 6.3 and $4.3 \mathrm{Ma}$.

$\mathrm{MAR}_{\mathrm{Fe}}$ records (Fig. 4d) vary between 0.025 and $0.2 \mathrm{~g} / \mathrm{cm}^{2} / \mathrm{ky}$ at Site 1165 and between 0.06 and $0.6 \mathrm{~g} /$ $\mathrm{cm}^{2} / \mathrm{ky}$ at Site 1095 . MAR ter and MAR $\mathrm{Fe}$ are strongly coupled $(r=0.98)$ through LSR and therefore exhibit very similar trends.

\section{Discussion}

\subsection{Long-term changes in sea ice coverage}

The congruence of $\mathrm{DEP}_{\text {opal }}$ records from Sites 1165 and 1095 (Fig. 3c) suggests that biological productivity at the Prydz Bay continental rise and the Antarctic Peninsula margin was similar throughout the late Miocene and early Pliocene.

The most prominent feature of the $\mathrm{DEP}_{\text {opal }}$ records from Sites 1165 and 1095 is the increase in biological productivity occurring from $\sim 5.8$ to $5.2 \mathrm{Ma}$, which indicates a significant reduction in sea ice coverage around Antarctica from the late Miocene to the early Pliocene. This reduction, and the following period of high $\mathrm{DEP}_{\text {opal }}$, is in agreement with an early Pliocene warm period as documented for the Southern Ocean using paleontological evidence (e.g. Abelmann et al., 1990; Bohaty and Harwood, 1998; Whitehead et al., 2001), sedimentological data (e.g. Hillenbrand and Fütterer, 2001; Hillenbrand and Ehrmann, 2005-this issue), and isotope records (e.g. Hodell and Venz, 1992; Billups et al., 1999).

The Pliocene warm period was likely associated with a deeper carbonate compensation depth (CCD) in the western equatorial Atlantic (King et al., 1997), and with a stronger flow of Northern Component Water (NCW) (Kwiek and Ravelo, 1999). It is not clear yet if the strengthened thermohaline circulation (THC) after $\sim 5.0 \mathrm{Ma}$ was the cause or the consequence of the Pliocene warming. The latter is suggested by model studies (Kim and Crowley, 2000) that propose an atmospheric $\mathrm{CO}_{2}$ increase as the cause for reduced sea 
ice concentration which could have created a meridional deepwater gradient and enhanced THC.

Superimposed on the higher level of $\mathrm{DEP}_{\text {opal }}$ after $\sim 5.2 \mathrm{Ma}$ are prominent productivity maxima occurring at $\sim 5.0, \sim 4.3$, and $3.7 \mathrm{Ma}$ that may indicate maximum NCW influx into the Southern Ocean. Sea surface temperature (SST) estimates based on the abundance of silicoflagellate at Site 1165 indicate that mean annual SST was approximately $4.0{ }^{\circ} \mathrm{C}$ at $4.3 \mathrm{Ma}$ and $5.0{ }^{\circ} \mathrm{C}$ at $3.7 \mathrm{Ma}$, which is 4.5 and $5.5^{\circ} \mathrm{C}$ above the modern level, respectively (Whitehead and Bohaty, 2003). Reduced sea ice conditions around 4.3 Ma are also evident from the diatom assemblage of the Sørsdal Formation in the Vestfold Hills (Whitehead et al., 2001).

The $\mathrm{DEP}_{\text {opal }}$ record from Sites 1165 and the higher resolution photospectrometer record exhibit several minima in deposition of biogenic silica between $\sim 7.0$ and 5.6 Ma (Fig. 3). The limited resolution of the Site 1165 chronology does not allow for a detailed correlation of the color curve with $\delta^{18} \mathrm{O}$ records, but the high number of excursions suggests that lows in productivity, associated with sea ice growth, occurred frequently in Antarctic waters during the late Miocene. These lows may have been linked to cooling events observed in astronomically dated benthic oxygen isotope curves (e.g. Hodell et al., 1994; Shackleton et al., 1995; Vidal et al., 2002).

\subsection{Long-term changes in Antarctic glaciation}

In Fig. 4 we compare long-term trends in $\mathrm{MAR}_{\text {ter }}$ and $\mathrm{MAR}_{\mathrm{Fe}}$ at the Prydz Bay continental rise (Site 1165) to similar records from the Antarctic Peninsula margin (Site 1095) and to a benthic oxygen isotope record (Billups, 2002) from ODP Site 1088 (Agulhas Ridge, Southern Ocean). Furthermore, two records from the Kerguelen Plateau (ODP Leg 119) are shown (Fig. 4b): The MAR ter time series from Site 745 (Joseph et al., 2002) and the seawater $\delta^{18} \mathrm{O}$ record derived from $\mathrm{Mg} / \mathrm{Ca}$ measurements at Site 747 (Billups and Schrag, 2003).

Overall amplitudes of MAR $\mathrm{Mer}_{\text {ter }}$ and $\mathrm{MAR}_{\mathrm{Fe}}$ vary up to an order of magnitude indicating that large changes in sediment delivery from the Antarctic continent occurred throughout the late Miocene and the Pliocene. The periods of elevated terrigenous supply reflect repeated advances of grounded ice masses on to the continental shelf (likely to the shelf break), which points to an extensive but variable ice coverage on Antarctica.

Two intervals displaying higher accumulation of terrigenous sediment components occur synchronously at both sites at about 5 and $7 \mathrm{Ma}$ (Fig. 4cd). Apparently, they represent Antarctic wide events. Absolute values are up to four times lower at Site 1165 , likely due to a higher degree of downslope transport at Site 1095 (Shipboard Scientific Party, 1999). Additional maxima at $\sim 6.3,4.6$ and $\sim 4.2 \mathrm{Ma}$ in terrigenous accumulation that occur at Site 1095 are not found at Site 1165 but seem to be reflected in the Kerguelen Plateau record of Site 745 (Joseph et al., 2002). These maxima might represent Antarctic wide events, but with the enhanced terrigenous supply bypassing Site 1165 . The prominent event at $\sim 6.3 \mathrm{Ma}$ is possibly masked by a short $(<0.37 \mathrm{Ma})$ disconformity at Site 1165 (Florindo et al., 2003).

The most pronounced maximum in terrigenous supply within the investigated time interval occurs at about $7 \mathrm{Ma}$. At this time foraminiferal carbon isotope records from different regions display a prominent decrease, termed the late Miocene $\delta^{13} \mathrm{C}$ shift (e.g. Hodell and Kennett, 1986; Wright et al., 1991; Hodell et al., 2001). In the Southern Ocean this shift is likely caused by a reduction of NCW flow (Billups, 2002). The carbon isotope shift may reflect increased erosion of organic carbon from terrigenous soils and shelf sediments during a drop in sea level as a result of Antarctic glaciation (e.g. Berger and Vincent, 1986; Bickert et al., 2004). Further evidence for a larger global ice volume comes from an increase in benthic foraminiferal $\delta^{18} \mathrm{O}$ observed at Site 1088 (Agulhas Ridge, Billups, 2002, Fig. 4a) and the Sale Briqueterie drill core (Morocco, Hodell et al., 1994). On the other hand, foraminiferal $\delta^{18} \mathrm{O}$ values at North Atlantic Site 982 remain relatively constant during this time interval (Hodell et al., 2001). Thus the interpretation of higher terrigenous supply to Sites 1165 and 1095 as indicators of larger Antarctic ice sheets implies that intermediate water temperature changes in the subpolar North Atlantic must have masked the ice volume signal at Site 982.

A reduction in $\mathrm{MAR}_{\text {ter }}$ at Sites 1095 and 1165 occurs at $\sim 6.6 \mathrm{Ma}$ (Fig. $4 \mathrm{c}$ ), which indicates either significantly reduced ice volume or a stabilization of the existing ice sheets. At this time, a rather sudden 
change in deep water distribution is documented for the Southern Ocean (Wright et al., 1991). According to Billups (2002), the relative contribution of North Atlantic Deep Water (NADW), which might have been absent before $\sim 6.6 \mathrm{Ma}$, increased to modern values between $\sim 6.6$ and $6.0 \mathrm{Ma}$. It is likely that this NADW flow warmed the Circumpolar Deep Water (CDW) and thus led to a reduction in Antarctic ice volume. However, these changes are not seen in our $\mathrm{DEP}_{\text {opal }}$ records (Fig. 3c), although we would expect a strong impact of CDW temperature change on the overlying surface waters and on the survival of sea ice (e.g. Hofmann et al., 1996; Jacobs and Comiso, 1997).

The increased deposition of terrigenous detritus from 5.2 to $4.8 \mathrm{Ma}$ at Sites 1095 and 1165 coincides with higher accumulation rates of terrigenous sediment (Fig. 4b) at the east Kerguelen Ridge sediment drift (Joseph et al., 2002). We conclude that major pulses of sediment delivery at the Antarctic continental rise indicate significant glacial advances at the Miocene/Pliocene boundary that concurred with a general reduction in sea ice coverage inferred from the $\mathrm{DEP}_{\text {opal }}$ record (Fig. 3c). Seismic and sedimentological studies give evidence that grounded ice was at least temporarily present on the East and West Antarctic continental shelves during the early Pliocene (e.g. Hillenbrand and Ehrmann, 2001; Bart, 2001; Passchier et al., 2003). An increase in global ice volume at $\sim 5 \mathrm{Ma}$ is indicated by the oxygen isotope composition of seawater calculated from combined $\delta^{18} \mathrm{O}$ values and $\mathrm{Mg} / \mathrm{Ca}$ ratios in benthic foraminifera at Site 747 (Billups and Schrag, 2003) and by a significant eustatic low-stand (Haq et al., 1987; Greenlee and Moore, 1988; Krantz, 1991).

Our records point to a synchronous expansion of the East and West Antarctic ice sheet during a time period characterized by relatively warm sea surface temperatures in the Southern Ocean. An explanation for ice expansion during climate warming was given by Prentice and Matthews (1991), who postulated that warming of Southern Ocean surface water would increase snowfall over the continent ("snowgun hypotheses"). This would lead to more ice, to faster ice flow and to an increase in basal frictional melting at the base of glaciers. The warming of Southern Ocean waters may have been strengthened by an increase in the relative flux of NCW because the production of cooler AABW was probably limited when grounded ice was present on the shelves (Weyl, 1968). This hypothesis is corroborated by the benthic oxygen isotope data from Site 1088 (Fig. 4a). The values stay at a constant level around 5.0 Ma suggesting that the increase in global ice volume was balanced by the counteracting warming of the deep water masses. According to our records the period of enhanced terrigenous supply ended at $\sim 4.9$ Ma likely due to further warming and subsequent retreat of the ice sheets.

It is important to note that the two intervals of higher $\mathrm{MAR}_{\text {ter }}$ are occurring under very different oceanic boundary conditions. While oxygen isotope records from the Southern Ocean (Billups, 2002) and other areas (e.g. Hodell et al., 2001) document a global cooling for the interval $\sim 7.0-6.6 \mathrm{Ma}$, a warming of Antarctic surface water at $\sim 5.3-4.9 \mathrm{Ma}$ is indicated by our $\mathrm{DEP}_{\text {opal }}$ records as well as by other climate records from the Southern Ocean (e.g. Abelmann et al., 1990; Hodell and Venz, 1992; Barker, 1995; Billups et al., 1999, Whitehead and Bohaty, 2003). NCW contribution to Southern Ocean deep water, calculated from Southern Ocean/Pacific and Southern Ocean/North Atlantic benthic $\delta^{13} \mathrm{C}$ gradients, was low $(<10 \%)$ from $\sim 8.0-6.5 \mathrm{Ma}$ and higher than the modern value $(33 \%)$ around $5.0 \mathrm{Ma}$ (Billups, 2002). This suggest that ice expansions and instabilities of the Antarctic ice sheet can occur during times of global climate cooling as well during periods of significant warming. This variability, which must have had a major influence (tens of meters) on global sea level, may not be related to climate alone but also to the nature of the ice sheet itself (e.g. Anderson et al., 1991; Hallet et al., 1996). There is evidence that fast flowing, polythermal glaciers existed during the late Miocene and early Pliocene (Hambrey and McKelvey, 2000). The Neogene Antarctic ice masses may have been more sensitive to minor climate change than the recent ice sheets that are cold-based and frozen to the bed.

\subsection{Cyclicity at Site 1165}

At Site 1165 sediments bearing high amounts of biogenic material alternated with highly terrigenous deposits since earliest Miocene time (Shipboard 

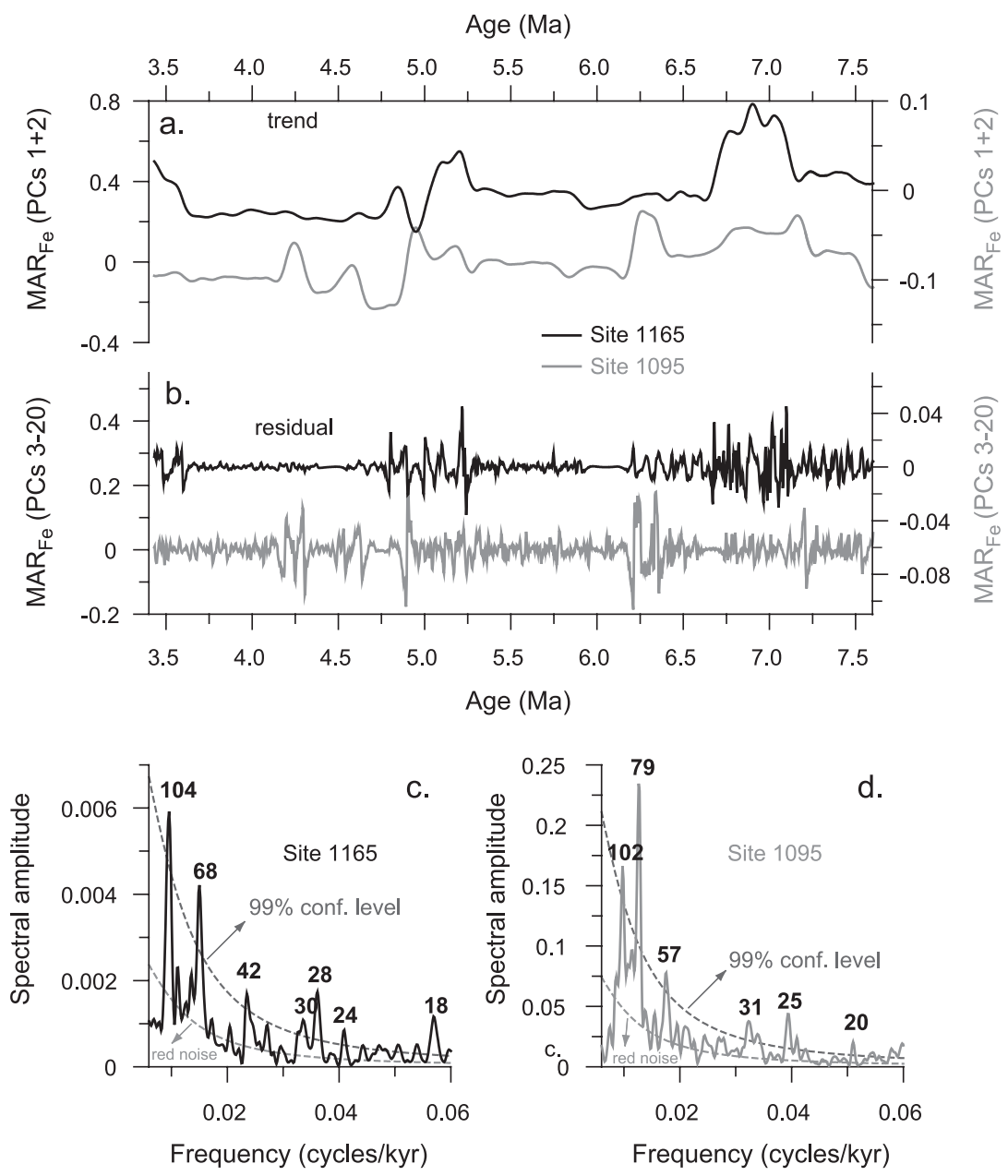

Fig. 5. Results of spectral analyses. Principal components obtained from Singular Spectrum Analyses (SSA) were used to reconstruct trend (a) and cyclic components (b) of the $\mathrm{MAR}_{\mathrm{Fe}}$ records from Sites 1165 and 1095. (c-d) Power spectra of series shown in (b) (6-db bandwidth $=0.0016$ ).

Scientific Party, 2001). Spectral analyses performed on depth series of diffuse spectral reflectance, multisensor core logs, and XRF scan data of selected intervals demonstrate that variance is concentrated at orbital frequencies, as predicted by the Milankovitch theory (e.g. Shipboard Scientific Party, 2001; Grützner et al., 2003). The $\mathrm{MAR}_{\mathrm{Fe}}$ record obtained for Sites 1165 (Fig. 4d), with an average time resolutions of $\sim 0.7 \mathrm{ky}$, exhibits cyclic changes that are superimposed on the long-term trend.

A spectrum of the $\mathrm{MAR}_{\mathrm{Fe}}$ record (Fig. 5) illustrates the general structure of the time interval between 3.4 and 7.6 Ma. Since an orbitally tuned timescale is not yet available for the whole time interval the analysed time series is based on magnetostratigraphy. This relatively simple ("untuned") time scale does not account for changes in sedimentation rate between age control points and thus may degrade some evidence of the ice sheet's true orbital sensitivity. On the other hand the investigated time series is not "biased" by any tuning procedure. To partition the high-resolution records into the trend and different orbital bands the time series were resampled at a resolution of $3 \mathrm{ky}$ and the number of embedding dimensions for the Singular 
Spectrum Analysis (SSA) was set to 20. The leading principal components (1 and 2) of the SSA reveal the trends that are strongly coupled to changes in LSR (Fig. 5a). The residuals (3 to 20) represent cyclic variations and noise components of the $\mathrm{MAR}_{\mathrm{Fe}}$ time series records (Fig. 5b). Cyclicities are predominantly driven by changes in iron content $(<9 \%$ standard deviation) with a minor contribution of density variations ( $<3 \%$ standard deviation).

The power spectrum for Site 1165 (Fig. 5c) calculated over the $\mathrm{MAR}_{\mathrm{Fe}}$ residual shows significant cyclic components exceeding the $99 \%$ confidence level. The concurrence of the spectral amplitude maxima at $\sim 104, \sim 42,24$, and 18 ky with astronomical cycles of eccentricity (100 ky), obliquity (41 ky) and precession (19-23 ky) provides clear evidence for an external forcing mechanism driving the observed $\mathrm{MAR}_{\mathrm{Fe}}$ changes at Site 1165 .

Besides the primary Milankovitch cycles other prominent spectral peaks appear in the Site 1165 $\mathrm{MAR}_{\mathrm{Fe}}$ record at 68 and $28 \mathrm{ky}$ (Fig. 5c). These periodicities are likely resulting from nonlinear interference between the strong $104 \mathrm{ky}$ peak and the $42 \mathrm{ky}$ peak (since $1 / 42-1 / 104=1 / 70$ and $1 / 42+1$ / $104=1 / 29$ ), and are also described for other climate records (e.g. Ruddiman et al., 1989; Rea, 1994).

Overall, the results from spectral analyses at Site 1165 indicate that cyclic changes in the supply of glaciogenic debris from East Antarctica occur at orbital frequencies during the late Miocene and early Pliocene and thus provide evidence for a dynamic and likely wet-based East Antarctic Ice Sheet. This dynamic behavior of the EAIS implies that a significant proportion of the variability seen in oxygen isotope records of the late Miocene reflects Antarctic ice-volume changes.

\subsection{Cyclicity at Site 1095}

In contrast to Site 1165 the $\mathrm{MAR}_{\mathrm{Fe}}$ record obtained for Site 1095 does not show such clear evidence for orbital-scale cyclicity (Fig. 5d). This finding is in agreement with spectral analyses performed on core logging (magnetic susceptibility, chromaticity parameter $a^{*}$, Pudsey, 2001) and downhole logging data (thorium/potassium ratio, natural gamma radiation, Lauer-Leredde et al., 2002) from Site 1095. Specifically, the strong spectral density maximum at the 41-ky obliquity periodicity found at 1165 is absent at 1095 , instead there is a strong 57 ky cyclicity (Fig. 5d). Assuming that the stratigraphy used was not sufficiently in error to mask orbital sensitivity one possible explanation for the absence of 41-ky cycles in the sedimentary record at Site 1095 is that for long periods of the ice sheet history, ice sheet volume changes were autocyclic rather than orbitally driven (e.g. Pudsey, 2001; Barker and Camerlenghi, 2002). Taken into account the strong orbital control at Site 1165, this would imply that the response of the Antarctic Peninsula ice sheet to orbital forcing was very different from that of the EAIS. Iorio et al. (in press) found evidence for orbital control in late Pliocene to Pleistocene sections of Antarctic Peninsula margin drilling locations (Sites 1095, 1096 and 1101). Thus we would argue that the absence of clear evidence for dominant orbital cyclicity in late Miocene to Pliocene sections at Site 1095 suggests that diagenetic or sedimentary processes like turbiditic sedimentation distorted the record.

\subsection{Evolution and origin of $41 \mathrm{ky}$ variability at the East Antarctic margin}

In order to study the obliquity modulation in the strength of terrigenous supply the Site $1165 \mathrm{MAR}_{\mathrm{Fe}}$ record was bandpass filtered at $41 \mathrm{ky}$ using a harmonic filtering algorithm designed for unevenly spaced time series. The resulting signal (Fig. 6) reveals that the obliquity cycles in $\mathrm{MAR}_{\mathrm{Fe}}$ had a higher amplitude during the time intervals $~ 7.2-6.6$ and $\sim 5.2-4.8$ Ma likely indicating amplified variations in Antarctic ice volume on orbital time scales.

An explanation for these amplifications could arise from the fact that the time intervals of enhanced terrigenous supply and inferred ice sheet expansion concur with maximum variance in orbital obliquity (Fig. 6a). Obliquity variations (Laskar, 1990) dominate the mean annual interhemispheric gradient in insolation that controls the atmospheric meridional flux of heat, moisture, and latent energy from low to high latitudes. There is evidence from the Vostok ice core deuterium excess record that atmospheric moisture supply to the Antarctic ice sheet (Vimeux et al., 1999) over the last $150 \mathrm{ky}$ was strongly linked to this interhemispheric gradient. Recently, Raymo and 


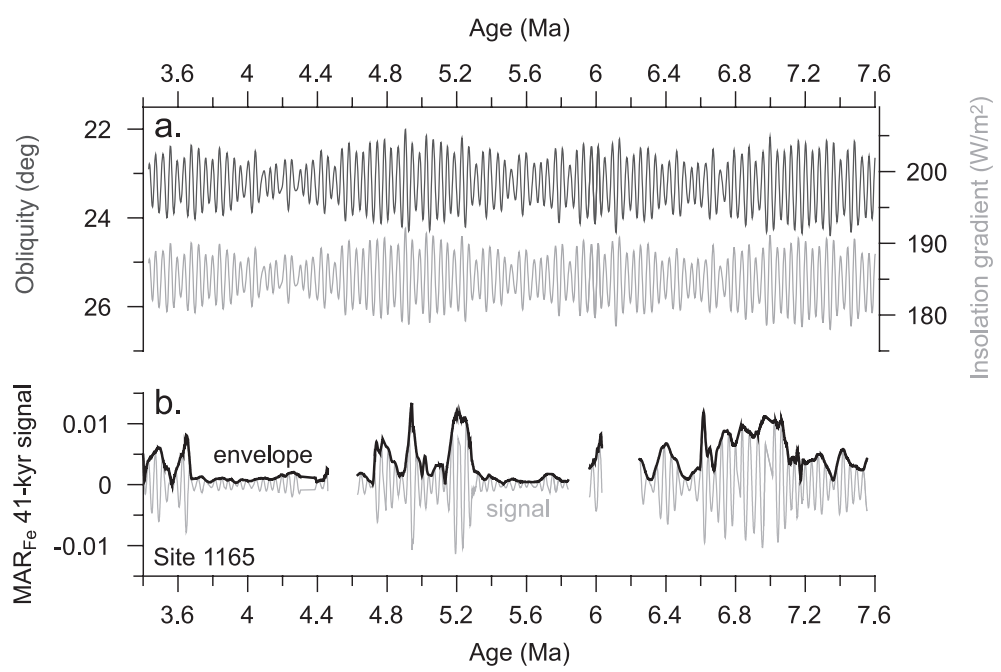

Fig. 6. (a) Earth's obliquity (dark) and mean annual insolation gradient (light) between $25^{\circ} \mathrm{S}$ and $70^{\circ} \mathrm{S}$ (Laskar, 1990). (b) Temporal changes of 41-ky signal component in the $\mathrm{MAR}_{\mathrm{Fe}}$ record at Site 1165 calculated by a harmonic filtering algorithm (modified after Ferraz-Mello, 1981) using a sliding window of $82 \mathrm{ky}$ width (half-amplitude bandwidth $=0.025 \mathrm{ky}^{-1}$ ).

Nisancioglu (2003) proposed that poleward flux of moisture, which fuels ice sheet growth, plays a dominant role in controlling the $41 \mathrm{ky}$ cycles seen in isotope records of the time interval 3 to $1 \mathrm{Ma}$. The interhemispheric insolation gradient may also have played a major role in the amplitude modulation of Antarctic ice volume fluctuations during the late Miocene/early Pliocene. The mass balance of an ice sheet is set by the relative rates of accumulation and ablation. The rate of ablation is controlled by local incoming solar radiation, local atmospheric temperature, and ice shelf melting by impinging warm ocean water at the periphery of an ice sheet. The rate of accumulation is controlled by the amount of moisture available for precipitation as well as the local temperature. During periods of low obliquity, interhemispheric insolation gradient and poleward flux of energy were high which likely enhanced moisture supply to the ice sheets. Snow and ice would expand and raise the surface albedo causing a further decrease in local temperature. Furthermore, summer temperatures were likely too low to compensate the winter ice growth through melting. During the following time interval of increasing obliquity a lowering of the interhemispheric insolation gradient reduces evaporation necessary for ice sheet growth and warmer summers led to higher melting rates. Model studies indicate that a temperature rise of only a few ${ }^{\circ} \mathrm{C}$ imposed for just a few hundred years can result in considerable shrinkage of the Antarctic ice sheets (e.g. Warner and Budd, 1998; Huybrechts, 2002). Thus maximum ice recessions should occur during times of high obliquity. The scenario of waxing and waning of ice masses associated with obliquity changes likely resulted in a strong $\sim 41 \mathrm{ky}$ periodicity of terrigenous supply, and furthermore would explain why the highest $\mathrm{MAR}_{\text {ter }}$ at Site 1165 are observed for time intervals of extreme obliquity changes. Further insights into these mechanisms should be possible as soon as more accurate (e.g. astronomically tuned) age models for the Antarctic drill sites over longer time intervals become available.

\section{Conclusions}

At ODP Sites 1165 and 1095 opal depositional rates calculated for the time interval between 7.6 and 3.5 Ma show a pronounced increase at the Miocene/ Pliocene boundary. This increase occurred synchronous at the East and West Antarctic continental margins likely reflecting a significant reduction in annual sea ice extent due to Southern Ocean warming. 
East and West Antarctic glaciation inferred from mass accumulation rates of terrigenous matter and iron intensified at $\sim 7.2-6.6$ and $\sim 5.2-4.8 \mathrm{Ma}$. The late Miocene period of ice sheet build-up was accompanied by cold water temperatures in the Southern Ocean, whereas the early Pliocene ice sheet growth apparently occurred during a period of Southern Ocean warming.

A dynamic behavior with waxing and waning of the EAIS even during these intervals is indicated by high amplitude changes in the $41 \mathrm{ky}$ band of iron accumulation pointing to strong orbital control of sedimentation changes at the Prydz Bay continental margin.

Ice volume fluctuations predominantly occurred during times of maximum variability in Earth's obliquity. We assume that the mean annual interhemispheric insolation gradient, which is controlled by obliquity, influences the moisture flux to the southern high latitudes and thus exerts the dominant control on precipitation and ice growth on Antarctica.

\section{Acknowledgements}

We acknowledge the work of the crew, technicians, and scientific staff of ODP Legs 178 and 188. This research used samples provided by the Ocean Drilling Program (ODP). The ODP is sponsored by the U.S. National Science Foundation (NSF) and participating countries under management of Joint Oceanographic Institutions (JOI). We would like to thank Sandra Passchier and Jason Whitehead for their constructive reviews. Thanks also to Helen McGregor for helping to improve the style of this contribution. Funding for this research was provided by the Deutsche Forschungsgemeinschaft (DFG), and by the Italian Antarctic Program (PNRA).

\section{References}

Abelmann, A., Gersonde, R., Spiess, V., 1990. Pliocene-Pleistocene paleoceanography in the Weddell Sea-siliceous microfossil evidence. In: Bleil, U., Thiede, J. (Eds.), Geological History of the Polar Oceans: Arctic versus Antarctic. NATO ASI Ser. C, vol. 308. Kluwer Academic Publishers, Dordrecht, pp. $729-759$.
Acton, G.D., Guyodo, Y., Brachfeld, S.A., 2002. Magnetostratigraphy of sediment drifts on the continental rise of West Antarctica (ODP Leg 178, Sites 1095, 1096, and 1101). In: Barker, P.F., Camerlenghi, A., Acton, G.D., Ramsay, A.T.S. (Eds.), Proceedings of the Ocean Drilling Program, Scientific Results, vol. 178, pp. 1-33. (College Station, TX (CD-ROM). Available from: Ocean Drilling Program, Texas A\&M University, College Station, TX 77845-9547, U.S.A.).

Anderson, J.B., Kennedy, D.S., Smith, M.J., Domack, E.W., 1991. Sedimentary facies associated with Antarctica's floating ice masses. In: Anderson, J.B., Ashley, G.M. (Eds.), Glacial Marine Sedimentation, Paleoclimatic Significance. vol. 261. Geological Society of America, Boulder, CO, pp. 1-25.

Archer, D., Lyle, M., Rodgers, K., Froelich, P., 1993. What controls opal preservation in tropical deep-sea sediments? Paleoceanography $8,7-21$.

Armand, L.K., 2000. An ocean of ice; advances in the estimation of past sea ice in the Southern Ocean. GSA Today 10 (3), 1-7.

Balsam, W.L., Damuth, J.E., Schneider, R.R., 1997. Comparison of shipboard vs. shore-based spectral data from Amazon-Fan Cores: implications for interpreting sediment composition. In: Flood, R.D., Piper, D.J.W., Klaus, A., Peterson, L.C. (Eds.), Proc. ODP, Sci. Results, vol. 155. Ocean Drilling Program, College Station, TX, pp. 193-215.

Barker, P.F., 1995. The proximal marine sediment record of Antarctic climate since the Late Miocene. In: Cooper, A.K., Barker, P.F., Brancolini, G. (Eds.), Geology and Seismic Stratigraphy of the Antarctic Margin. Antarct. Res. Ser., vol. 68. AGU, Washington, DC, pp. 25-57.

Barker, P.F., Camerlenghi, A., 2002. Glacial history of the Antarctic Peninsula from Pacific margin sediments. In: Barker, P.F., Camerlenghi, A., Acton, G.D., Ramsay, A.T.S. (Eds.), Proc. ODP, Sci. Results, vol. 178, pp. 1-40. ((CD-ROM). Available from: Ocean Drilling Program, Texas A\&M University, College Station, TX 77845-9547, U.S.A.).

Bart, P.J., 2001. Did the Antarctic ice sheets expand during the early Pliocene? Geology 29, 67-70.

Berger, W.H., Vincent, E., 1986. Deep-sea carbonates: reading the carbon-isotope signal. Geol. Rundsch. 75, 249-269.

Bickert, T., Haug, G., Tiedemann, R., 2004. Late Neogene benthic stable isotope record of Ocean Drilling Program Site 999: Implications for Caribbean paleoceanography, organic carbon burial, and the Messinian Salinity Crisis. Paleoceanography 19 (PA1023), 11.

Billups, K., 2002. Late Miocene through early Pliocene deep water circulation and climate change viewed from the sub-Antarctic South Atlantic. Paleogeogr., Paleoclimat., Paleoecol. 185 (3-4), 287-307.

Billups, K., Schrag, D.P., 2003. Application of benthic foraminiferal $\mathrm{Mg} / \mathrm{Ca}$ ratios to questions of Cenozoic climate change. Earth Planet. Sci. Lett. 209, 181-195.

Billups, K., Ravelo, A.C., Zachos, J.C., 1998. Early Pliocene deep water circulation in the western Equatorial Atlantic; implications for high-latitude climate change. Paleoceanography 13 (1), 84-95.

Billups, K., Ravelo, A.C., Zachos, J.C., Norris, R.D., 1999. Link between oceanic heat transport, thermohaline circulation, and 
the Intertropical Convergence Zone in the early Pliocene Atlantic. Geology 27 (4), 319-322.

Bohaty, S.M., Harwood, D.M., 1998. Southern Ocean Pliocene paleotemperature variation from high resolution silicoflagellate biostratigraphy. Mar. Micropaleontol. 33, 241-272.

Burckle, L.H., Mortlock, R., 1998. Sea-ice extent in the Southern Ocean during the last glacial maximum; another approach to the problem. In: Budd, W.F. (Ed.), Papers from the International Symposium on Antarctica and Global Change; Interactions and Impacts. Annals of Glaciology, International Glaciological Society, Cambridge, International, vol. 27, pp. 302-304.

Cande, S.C., Kent, D.V., 1995. Revised calibration of the geomagnetic polarity timescale for the Late Cretaceous and Cenozoic. J. Geophys. Res. 100, 6093-6095.

DeMaster, D.J., Ragueneau, O., Nittrouer, C.A., 1996. Preservation efficiencies and accumulation rates for biogenic silica and organic $\mathrm{C}, \mathrm{N}$, and $\mathrm{P}$ in high-latitude sediments: the Ross Sea. J. Geophys. Res., C8 (101), 18501-18518.

Ehrmann, W.U., Grobe, H., Fütterer, D.K., 1991. Late Miocene to Holocene glacial history of East Antarctica revealed by sediments from Sites 745 and 746. In: Barron, J., Larsen, B., et al., (Eds.), Proceedings of the Ocean Drilling Program, Scientific Results, vol. 119. Ocean Drilling Program, College Station, TX, pp. 239-251.

Escutia, C., Nelson, C.H., Acton, G.D., Eittreim, S.L., Cooper, A.K., Warnke, D.A., Jaramillo, J.M., 2002. Current controlled deposition on the Wilkes Land continental rise, Antarctica. In: Stow, D.A.V., Faugeres, J.-C., Howe, J., Pudsey, C.J., Viana, A. (Eds.), Deep-Water Contourite Systems: Modern Drifts and Ancient Series, Seismic and Sedimentary Characteristics. Geol. Soc. Mem., vol. 22, pp. 373-384 (London).

Ferraz-Mello, S., 1981. Estimation of periods from unequally spaced observations. Astron. J. 86, 619-624.

Florindo, F., Bohaty, S.M., Erwin, P.S., Richter, C., Roberts, A.P., Whalen, P.A., Whitehead, J.M., 2003. Magnetobiostratigraphic chronology and palaeoenvironmental history of Cenozoic sequences from ODP sites 1165 and 1166, Prydz Bay, Antarctica. Paleogeogr., Paleoclimat., Paleoecol. 198, 69-100.

Gersonde, R., Hodell, D.A., Blum, P., et al., 1999. Proc. ODP, Init. Repts., 177 (CD-ROM). Available from: Ocean Drilling Program, Texas A\&M University, College Station, TX 778459547, U.S.A.

Greenlee, S.M., Moore, T.C., 1988. Recognition and interpretation of depositional sequences and calculation of sea-level changes from stratigraphic data-Offshore New Jersey and Alabama, Tertiary. In: Wilgus, C.K., et al., (Eds.), SeaLevel Changes: An Integrated Approach. Society of Economic Paleontologists and Mineralogists Special Publication, vol. 42, pp. 329-353.

Grützner, J., 2003. Data report: multisensor core logging data, coarse-fraction grain-size analyses, and biogenic silica content of upper Miocene-lower Pliocene sediments, ODP Site 1165. In: Cooper, A.K., O’Brien, P.E., Richter, C. (Eds.), Proceedings of the Ocean Drilling Program, Scientific Results, vol. 188, pp. 1-16. ((CD-ROM). Available from: Ocean Drilling Program, Texas A\&M University, College Station, TX 77845-9547, U.S.A.).
Grützner, J., Rebesco, M.A., Cooper, A.K., Forsberg, C.F., Kryc, K.A., Wefer, G., 2003. Evidence for orbitally controlled size variations of the East Antarctic Ice Sheet during the late Miocene. Geology 31 (9), 777-780.

Hallet, B., Hunter, L., Bogen, J., 1996. Rates of erosion and sediment evacuation by glaciers: a review of field data and their implications. Glob. Planet. Change 12, 213-235.

Hambrey, M.J., McKelvey, B., 2000. Major Neogene fluctuations of the East Antarctic ice sheet: stratigraphic evidence from the Lambert Glacier region. Geology 28 (10), 887-890.

Hambrey, M.J., Ehrmann, W.U., Larsen, B., 1991. Cenozoic glacial record of the Prydz Bay continental shelf, East Antarctica. In: Barron, J., Larsen, B., et al., (Eds.), Proceedings of the Ocean Drilling Program, Scientific Results, vol. 119. Ocean Drilling Program, College Station, TX, pp. 77-132.

Haq, B.U., Hardenbol, J., Vail, P.R., 1987. Chronology of fluctuating sea levels since the Triassic. Science 235, 1156-1167.

Harwood, D.M., Webb, P.-N., 1998. Glacial transport of diatoms in the Antarctic Sirius Group: Pliocene refrigerator. GSA Today 8 (1), 4-8.

Hays, J.D., Imbrie, J., Shackleton, N.J., 1976. Variations in the Earth's orbit: pacemaker of the ice ages. Science 194, $1121-1132$.

Hilgen, F.J., Krijgsman, W., Langereis, C.G., Lourens, L.J., Santarelli, A., Zachariasse, W.J., 1995. Extending the astronomical (polarity) time scale into the Miocene. Earth Planet. Sci. Lett. 136, 495-510.

Hillenbrand, C.-D., Ehrmann, W., 2001. Distribution of clay minerals in drift sediments on the continental rise west of the Antarctic Peninsula, ODP Leg 178, Sites 1095 and 1096. In: Barker, P.F., Camerlenghi, A., Acton, G.D., Ramsay, A.T.S. (Eds.), Proc. ODP, Sci. Results, vol. 178, pp. 1-29. ((CD-ROM). Available from: Ocean Drilling Program, Texas A\&M University, College Station, TX 77845-9547, U.S.A.).

Hillenbrand, C.-D., Ehrmann, W.U., 2005. Late Neogene to Quaternary environmental changes in the Antarctic Peninsula region: evidence from drift sediments. Global and Planetary Change 45, 131-149 (this issue).

Hillenbrand, C.-D., Fütterer, D.K., 2001. Neogene to Quaternary deposition of opal on the continental rise west of the Antarctic Peninsula. In: Barker, P.F., Camerlenghi, A., Acton, G.D., Ramsay, A.T.S. (Eds.), Proceedings of the Ocean Drilling Program, Scientific Results, vol. 178, pp. 1-33. (College Station, TX(CD-ROM). Available from: Ocean Drilling Program, Texas A\&M University, College Station, TX 77845-9547, U.S.A.).

Hodell, D.A., Kennett, J.P., 1986. Late Miocene-early Pliocene stratigraphy and paleoceanography of the South Atlantic and Southwest Pacific Ocean; A synthesis. Paleoceanography 1 (3), 285-311.

Hodell, D.A., Venz, K., 1992. Toward a high-resolution stable isotopic record of the Southern Ocean during the PliocenePleistocene (4.8 to 0.8 Ma). In: Kennett, J.D., Warnke, D.A. (Eds.), The Antarctic Paleoenvironment: A Perspective on Global Change. Antarct. Res. Ser., vol. 56. AGU, Washington, DC, pp. 265-310.

Hodell, D.A., Benson, R.H., Kent, D.V., Boersma, A., El Bied, K.R., 1994. Magnetostratigraphic, biostratigrahic, and stable 
isotope stratigraphy of an Upper Miocene drill core from the Salé Briqueterie (northwestern Morocco): A high-resolution chronology for the Messinian stage. Paleoceanography 9, $835-856$.

Hodell, D.A., Curtis, J.H., Sierro, F.J., Raymo, M.E., 2001. Correlation of late Miocene to early Pliocene sequences between the Mediterranean and North Atlantic. Paleoceanography 16 (2), $164-178$.

Hofmann, E.E., Klinck, J.M., Lascara, C.M., Smith, D.A., 1996. Water mass distribution and circulation west of the Antarctic Peninsula and Bransfield Strait. In: Ross, R.M, Hofmann, E.E., Quentin, L.B. (Eds.), Foundations for ecological research west of the Antarctic Peninsula. Antarct. Res. Ser., vol. 70, pp. $61-80$.

Huybrechts, P., 1993. Glaciological modelling of the Late Cenozoic East Antarctic ice sheet: stability or dynamism? Geogr. Ann., Ser. A $75,221-238$.

Huybrechts, P., 2002. Sea-level changes at the LGM fromicedynamic reconstructions of the Greenland and Antarctic ice sheets during the glacial cycles. Quat. Sci. Rev. 31, 203-221.

Iorio, M., Wolf-Welling, T., Moerz, T., in press. Orbital periodicities ( $\sim 21$ to $413 \mathrm{ky})$ in Plio-Pleistocene glacially-influenced drift sediments from Antarctic Peninsula ODP Sites 1095, 1096, 1101. Society for Sedimentary Geology, SEPM, 81.

Jacobs, S.S., Comiso, J.C., 1997. Climate variability in the Amundsen and Bellingshausen Seas. J. Climate 10, 697-709.

Jansen, J.H.F., van der Gaast, S.J., Koster, B., Vaars, A.J., 1998. CORTEX, a short shipboard XRF-scanner for element analysis in split sediment cores. Mar. Geol. 151, 143-153.

Joseph, L.H., Rea, D.K., van der Pluijm, B.A., Gleason, J.D., 2002. Antarctic environmental variability since the late Miocene: ODP Site 745, the East Kerguelen sediment drift. Earth Planet. Sci. Lett. 201, 127-142.

Kennett, J.P., Barker, P.F., 1990. Latest Cretaceous to Cenozoic climate and oceanographic developments in the Weddell Sea, Antarctica: an ocean-drilling perspective. In: Barker, P.F., Kennett, J.P., O'Connell, S.B., et al., (Eds.), Proceedings of the Ocean Drilling Program, Scientific Results, vol. 113. Ocean Drilling Program, College Station, TX, pp. 937-960.

Kennett, J.P., Hodell, D.A., 1995. Stability or instability of Antarctic ice sheets during warm climates. GSA Today 5 (1), 9-22.

Kim, S.-J., Crowley, T.J., 2000. Increased Pliocene North Atlantic deep water: cause or consequence of Pliocene warming? Paleoceanography 15 (4), 451-455.

King, T.A., Ellis, W.G., Murray, D.W., Shackleton, N.J., Harris, S., 1997. Miocene evolution of carbonate sedimentation at the Ceara Rise: a multivariate data/proxy approach. In: Shackleton, N.J., Curry, W.B., Richter, C., Bralower, T.J. (Eds.), Proceedings of the Ocean Drilling Program, Scientific Results, vol. 154. Ocean Drilling Program, College Station, TX, pp. 349-365.

Krantz, D.E., 1991. A chronology of Pliocene sea-level fluctuations; the U. S. middle Atlantic Coastal Plain record. In: Cronin, T.M., Dowsett, H.J. (Eds.), Pliocene Climates. Quaternary Science Reviews, vol. 10. Pergamon, Oxford, pp. 163-174.

Kuvaas, B., Leitchenkov, G., 1992. Glaciomarine turbidite and current-controlled deposits in Prydz Bay, Antarctica. Mar. Geol. $108,365-381$.
Kwiek, P.B., Ravelo, A.C., 1999. Pacific Ocean intermediate and deep water circulation during the Pliocene. Palaeogeogr. Palaeoclimatol. Palaeoecol. 154, 191-217.

Laskar, J., 1990. The chaotic motion of the solar system: a numerical estimate of the size of the chaotic zones. Icarus 88 , 266-291.

Lauer-Leredde, C., Briqueu, L., Williams, T., 2002. A wavelet analysis of physical properties measured downhole and on core from Holes 1095B and 1096C (Antarctic Peninsula). In: Barker, P.F., Camerlenghi, A., Acton, G.D., Ramsay, A.T.S. (Eds.), Proceedings of the Ocean Drilling Program, Scientific Results, vol. 178, pp. 1-43. ((CD-ROM). Available from: Ocean Drilling Program, Texas A\&M University, College Station, TX 77845-9547, U.S.A.).

Lear, C.H., Elderfield, H., Wilson, P.A., 2000. Cenozoic deep-sea temperatures and global ice volumes from $\mathrm{Mg} / \mathrm{Ca}$ in benthic foraminiferal calcite. Science 287, 269-272.

Lomb, N.R., 1976. Least-squares frequency analysis of unequally spaced data. Astrophys. Space Sci. 39, 447-462.

Michels, K.H., Kuhn, G., Hillenbrand, C.-D., Diekmann, B., Fütterer, D.K., Grobe, H., Uenzelmann-Neben, G., 2002. The southern Weddell Sea: combined contourite-turbidite sedimentation at the southeastern margin of the Weddell Gyre. In: Stow, D.A.V., Faugeres, J.-C., Howe, J., Pudsey, C.J., Viana, A. (Eds.), Deep-Water Contourite Systems: Modern Drifts and Ancient Series, Seismic and Sedimentary Characteristics. Geol. Soc. Mem., vol. 22, pp. 305-323 (London).

Müller, J.P., Schneider, R.R., 1993. An automated method for the determination of opal in sediments and particular matter. DeepSea Res. 40 (3), 425-444.

Murray, R.W., Miller, D.J., Kryc, K.A., 2000. Analysis of major and trace elements in rocks, sediments, and interstitial waters by inductively coupled plasma emission spectrometry. College Station, Texas, Ocean Drilling Program. Tech. Note 29, $30 \mathrm{pp}$.

Naish, T.R., Woolfe, K.J., Barrett, P.J., Wilson, G.S., Atkins, C., Bohaty, S.M., Bücker, C.J., Davey, F.J., Dunbar, G.B., Dunn, A.G., Fielding, C.R., Florindo, F., Hannah, M.J., Harwood, D.M., Henrys, S.A., Krissek, L.A., Lavelle, M., van der Meer, J., McIntosh, W.C., Niessen, F., Passchier, S., Powell, R.D., Roberts, A.P., Sagnotti, L., Scherer, R.P., Strong, C.P., Talarico, F., Verosub, K.L., Villa, G., Watkins, D.K., Webb, P.-N., Wonik, T., 2001. Orbitally induced oscillations in the East Antarctic ice sheet at the Oligocene/Miocene boundary. Nature 413, 719-723.

Passchier, S., O’Brien, P.E., Damuth, J.E., Januszczak, N., Handwerger, D.A., Whitehead, J.M., 2003. Pliocene-Pleistocene glaciomarine sedimentation in eastern Prydz Bay and development of the Prydz trough-mouth fan, ODP Sites 1166 and 1167, East Antarctica. Mar. Geol. 199, 279-305.

Pickard, J., Adamson, D.A., Harwood, D.M., Miller, G.H., Quilty, P.G., Dell, R.G., 1988. Early Pliocene marine sediments, coastline, and climate of East Antarctica. Geology 16, $158-161$.

Poore, R.Z., Sloan, L.C. (Eds.), 1996. Climates and climate variability of the Pliocene. Mar. Micropaleontol, vol. 27. Elsevier, Amsterdam. 
Prentice, M.L., Matthews, R.K., 1991. Tertiary ice sheet dynamics: the snow gun hypothesis. J. Geophys. Res., B 96 (4), 6811-6827.

Pudsey, C.J., 2001. Neogene record of Antarctic Peninsula glaciation in continental rise sediments: ODP Leg 178, Site 1095. In: Barker, P.F., Camerlenghi, A., Acton, G.D., Ramsay, A.T.S. (Eds.), Proceedings of the Ocean Drilling Program, Scientific Results, vol. 178, pp. 1-25. ((CD-ROM). Available from: Ocean Drilling Program, Texas A\&M University, College Station, TX 77845-9547, U.S.A.).

Ragueneau, O., Tréguer, P., Leynaert, A., Anderson, R.F., Brzezinski, M.A., DeMaster, D.J., Dugdale, R.C., Dymond, J., Fischer, G., Francois, R., Heinze, C., Maier-Reimer, E., MartinJézéquel, V., Nelson, D.M., Quéguiner, B., 2000. A review of the $\mathrm{Si}$ cycle in the modern ocean: recent progress and missing gaps in the application of biogenic opal as a paleoproductivity proxy. Glob. Planet. Change 26, 317-365.

Ravelo, A.C., Andreasen, D., 2000. Enhanced circulation during a warm period. Geophys. Res. Lett. 27, 1001-1004.

Raymo, M.E., Nisancioglu, K.H., 2003. The 41 kyr world: Milankovitch's other unsolved mystery. Paleoceanography 18 (1), 11-1-11-6.

Rea, D.K., 1994. The paleoclimatic record provided by eolian deposition in the deep sea: the geologic history of wind. Rev. Geophys. 32, 159-195.

Rebesco, M., 2003. Data report: numerical evaluation of diffuse spectral reflectance data and correlation with core photos, ODP Site 1165, Wild Drift, Cooperation Sea, Antarctica. In: Cooper, A.K., O’Brien, P.E., Richter, C. (Eds.), Proceedings of the Ocean Drilling Program, Scientific Results, vol. 188 ((CD-ROM). Available from: Ocean Drilling Program, Texas A\&M University, College Station, TX 77845-9547, U.S.A.)

Rebesco, M., Pudsey, C.J., Canals, M., Camerlenghi, A., Barker, P.F., Estrada, F., Giorgetti, A., 2002. Sediment drift and deep-sea channel systems, Antarctic Peninsula Pacific Margin. In: Stow, D.A.V., Faugeres, J.-C., Howe, J., Pudsey, J.C., Viana, A. (Eds.), Deep-Water Contourite Systems: Modern Drifts and Ancient Series Seismic and Sedimentary Characteristics. Geol. Soc. Mem., vol. 22, pp. 353-371 (London).

Röhl, U., Abrams, L.J., 2000. High-resolution, downhole, and nondestructive core measurements from Sites 999 and 1001 in the Caribbean Sea: application to the Late Paleocene Thermal Maximum. In: Leckie, R.M., Sigurdsson, H., Acton, G.D., Draper, G. (Eds.), Proceedings of the Ocean Drilling Program, Scientific Results, vol. 165. Ocean Drilling Program, College Station, TX, pp. 191-203.

Ruddiman, W.F., Raymo, M.E., Martinson, D.G., Clement, B.M., Backman, J., 1989. Pleistocene evolution: Northern Hemisphere ice sheets and North Atlantic Ocean. Paleoceanography 4 (4), $353-412$.

Scargle, J.D., 1982. Studies in astronomical time series analysis: II. Statistical aspects of spectral analysis of unevenly spaced data. Astrophys. J. 263 (2), 835-853.

Schlüter, M., Rutgers van der Loeff, M.M., Holby, O., Kuhn, G., 1998. Silica cycle in surface sediments of the South Atlantic. Deep-Sea Res. Part I. 45, 1085-1109.
Schulz, M., Mudelsee, M., 2002. REDFIT: estimating red-noise spectra directly from unevenly spaced paleoclimatic time series. Comput. Geotech. 28, 421-426.

Schulz, M., Berger, W.H., Sarnthein, M., Grootes, P.M., 1999. Amplitude variations of 1470-year climate oscillations during the last 100,000 years linked to fluctuations of continental ice mass. Geophys. Res. Lett. 26, 3385-3388.

Shackleton, N.J., Kennett, J.P., 1975. Late Cenozoic oxygen and carbon isotopic changes at DSDP Site 284: Implications for glacial history of the Northern Hemisphere and Antarctica. Initial Reports of the Deep Sea Drilling Project, vol. 29, pp. 801-807. (Lyttleton, N. Z. to Wellington, N. Z.; March-April 1973).

Shackleton, N.J., Crowhurst, S.J., Hagelberg, T., Pisias, N.G., Schneider, D.A., 1995. A new late Neogene time scale: application to Leg 138 sites. In: Pisias, N.G., Mayer, L.A., Janecek, T.R., Palmer-Julson, A., van Andel, T.H. (Eds.), Proceedings of the Ocean Drilling Program, Scientific Results, vol. 138. Ocean Drilling Program, College Station, TX.

Shipboard Scientific Party, 1999. Site 1095. In: Barker, P.F., Camerlenghi, A., Acton, G.D., et al. (Eds.), Proc. ODP, Initial Rep., vol. 178, pp. 1-173. ([CD-ROM]. Available from: Ocean Drilling Program, Texas A\&M University, College Station, TX 77845-9547, U.S.A.).

Shipboard Scientific Party, 2001. Site 1165. In: O’Brien, P.E., Cooper, A.K., Richter, C., et al., (Eds.), Proceedings of the Ocean Drilling Program, Initial Reports, vol. 188. Ocean Drilling Program, College Station, TX, pp. 1-193. ([CDROM]. Available from: Ocean Drilling Program, Texas A\&M University, College Station, TX 77845-9547, U.S.A.).

Smith, N.R., Zhaoqian, D., Knowles, K., Wright, S., 1984. Water masses and circulation in the region of Prydz Bay, Antarctica. Deep-Sea Res. 31 (9), 1121-1147.

Sugden, D.E., Marchant, D.R., Denton, G.H., 1993. The case for a stable East Antarctic ice sheet: the background. In: Sugden, D.E., Marchant, D.R., Denton, G. (Eds.), The Case for a Stable East Antarctica Ice Sheet. Proceedings, Geografiska Annaler. Series A: Physical Geography. Generalstabens Litografiska Anstlalt, Stockholm, Sweden, pp. 151-154.

Vautard, R., Yiou, P., Ghil, M., 1992. Singular spectrum analysis: a toolkit for short, noisy chaotic signals. Physica, D 58, 95-126.

Vidal, L., Bickert, T., Wefer, G., Röhl, U., 2002. Late Miocene stable isotope stratigraphy of SE Atlantic ODP Site 1085: relation to Messinian events. Mar. Geol. 180, 71-85.

Vimeux, F., Masson, V., Jouzel, J., Stievenard, M., Petit, J.R., 1999 (1 April). Glacial-interglacial changes in ocean surface conditions in the Southern Hemisphere. Nature 398, 410-413.

Warner, R.C., Budd, W.F., 1998. Modelling the long-term response of the Antarctic ice sheet to global warming. Ann. Glaciol. 27, $161-168$.

Webb, P.N., Harwood, D.M., McKelvey, B.C., Mercer, J.H., Stott, L.D., 1984. Cenozoic marine sedimentation and ice volume variation on the East Antarctic craton. Geology 12 (5), 287-291.

Weyl, P.K., 1968. The role of the oceans in climatic change: a theory of the ice ages. Causes of climatic change. Meteorological Monographs, INQUA, 7th Congr. Proc., vol. 5. 
American Meteorological Society, Boston, MA, United States, pp. $37-62$.

Whitehead, J.M., Bohaty, S.M., 2003. Pliocene summer sea surface temperature reconstruction using silicoflagellates from Southern Ocean ODP Site 1165. Paleoceanography 18 (3), 20-1-20-10.

Whitehead, J.M., Quilty, P.G., Harwood, D.M., McMinn, A., 2001. Early Pliocene paleonvironments of the Sørsdal Formation, Vestfold Hills, based on diatom data. Mar. Micropaleontol. 41, $125-152$.

Wilson, G.S., 1995. The neogene East Antarctic ice sheet: A dynamic or stable feature? Quat. Sci. Rev. 14 (2), 101-123.
Wong, A.P.S., Bindoff, N.L., Forbes, A., 1998. Ocean-ice shelf interactions and possible bottom water formation in Prydz Bay, Antarctica. Antarct. Res. Ser. 75, 173-187.

Wright, J.D., Miller, K.G., Fairbanks, R.G., 1991. Evolution of modern deepwater circulation: evidence from the late Miocene Southern Ocean. Paleoceanography 6 (2), 275-290.

Zachos, J.C., Pagani, M., Sloan, L.C., Thomas, E., Billups, K., 2001. Trends, rhythms, and aberrations in global climate $65 \mathrm{Ma}$ to present. Science 292, 686-693. 